Buletin JSJ, 1 (2), 2019, 63-69

Available online di: http://ejournal-balitbang.kkp.go.id/index.php/JSJ/index

\title{
PERFOMANSI KINERJA BUDIDAYA UDANG VANAME (Penaeus Vannamei) DI PT. BUANA BERSAMA JAYAINDO KABUPATEN PANDEGLANG, BANTEN
}

\section{PERFORMANCE OF VANAME SHRIMP CULTIVATION (Penaeus Vannamei) IN PT. BUANA BERSAMA JAYAINDO PANDEGLANG, BANTEN}

\author{
Yulia Musna Dewi \\ Program Studi Teknologi Akuakultur Sekolah Tinggi Perikanan \\ Jl. AUP Pasar Minggu, Jakarta Selatan \\ Email: yuliamusnadewi.tak52@gmail.com
}

\begin{abstract}
ABSTRAK
Udang vaname merupakan salah satu komoditas air payau dengan permintan yang cukup tinggi baik ekspor maupun impor. Namun masih banyak petambak udang vaname yang belum mengetahui prosedur dan proses budidaya yang benar. Tujuan dari penelitian ini adalah untuk menegetahui performansi kinerja budidaya udang vaname di PT. Buana Bersama Jayaindo Pandeglang Banten. Penelitian ini dilaksanakan tanggal 2 September sampai 30 Oktober 2019. Penelitian ini menggunakan pendekatan deskriptif. Hasil penelitian ini menunjukkan bahwa performansi kinerja budidaya pada siklus 2 belum mencapai target perusahan, dengan hasil rata-rata produtivitas $13,47 \mathrm{Ton} / \mathrm{Ha}$, SR $77 \%$, FCR 1,6, ABW 17,2 g/ekor dan ADG 0,26 g/ekor per hari.
\end{abstract}

Kata Kunci: Performansi kinerja budidaya, produktivitas

\begin{abstract}
Vaname shrimp is a brackish water commodity with a high demand both exports and imports. But there are still many shrimp vaname farmers who don't know the proper procedures and cultivation processes. The purpose of this study was to determine the performance of vaname shrimp culture at PT. Buana Bersama Jayaindo Pandeglang Banten. This research was conducted from 2 September to 30 October 2019. This research used a descriptive approach. The results of this field study indicate that the results of aquaculture performance in second cycle have not yet reached the company target, with the average yield of aquaculture performance in second cycle that is; produtivity 13.47 Ton / Ha, SR 77\%, FCR 1.6, $A B W 17.2 \mathrm{~g} / \mathrm{head}$ and $A D G 0.26 \mathrm{~g} / \mathrm{head}$ per day.
\end{abstract}

Keyword: Cultivation performance, productivity

\section{PENDAHULUAN}

Udang merupakan salah satu komoditas ekspor yang memiliki nilai ekonomi tinggi. Dan salah satu jenis udang yang permintaannya yang cukup tinggi baik di dalam maupun luar negeri yaitu udang vaname (Litopenaeus vannamei) (Gufron et al., 2017). Permintaan yang besar pada udang vaname di karenakan udang vaname memiliki beberapa keungulan seperti; tahan terhadap penyakit, mudah dibudidayakan, tingkat produktivitas yang tinggi. Selain itu, kebutuhan udang vaname akan kandungan protein pakan yang relatif rendah, dan tumbuh cepat, toleran terhadap suhu air, oksigen terlarut dan salinitas yang relatif rendah (Purnamasari et al., 2019). Udang vaname juga dapat dibudidayakan dengan padat tebar yang tinggi, karena vaname dapat memanfaatkan ruang dan pakan secara efisien (Fuady dan Nitisupardjo 2013). Menurut Ruswahono (2011) keunggulan udang vaname yaitu pertumbuhan yang cepat dan dapat dibudidayakan dengan kepadatan tinggi mencapai 92-100 ekor $/ \mathrm{m}^{2}$. 
Buletin JSJ, 1 (2), 2019, 63-69

Available online di: http://ejournal-balitbang.kkp.go.id/index.php/JSJ/index

Keberhasilan dalam produksi udang vaname juga dapat dilihat dari keberhasilan performansi kinerja budidayanya. Beberapa hal yang perlu dibahas dalam performansi kinerja budidaya udang vaname yaitu produktivitas, Survival Rate (SR), Food Convertion Ratio (FCR), Average Body Weight (ABW) dan Average Daily Growth (ADG).

PT. Buana Bersama Jayaindo merupakan salah satu perusahaan yang bergerak dalam bidang produksi udang vaname (Litopenaeus vannamei) yang terletak di Desa Tanjungan, Kecamatan Cikeusik Kabupaten Pandeglang Provinsi Banten. Tujuan melakukan penelitian ini adalah untuk mengevaluasi performansi kinerja budidaya udang vaname.

\section{BAHAN DAN METODE}

Penelitian ini dilaksanakan selama \pm 2 bulan dimulai dari tanggal 2 September sampai 30 Oktober 2019 dan bertempat di PT.Buana Bersama Jayaindo Desa Tanjungan, Kecamatan Cikeusik Kabupaten Pandeglang Provinsi Banten. Penelitian ini menggunakan pendekatan deskriptif dengan mengamati dan mengikuti seluruh rangkaian proses produksi di perusahaan. Data yang dikumpulkan meliputi semua komponen sumberdaya yang digunakan dalam proses produksi yaitu: bahan atau material yang digunakan, metode atau SOP yang dijalankan, sarana prasarana yang dimiliki dan tersebut termasuk data siklus sebelumnya. Performansi kinerja budidaya yang diukur meliputi produktivitas, SR, FCR, ABW dan ADG serta kualitas air, Yaitu sebagai berikut:

a. Produktivitas

$$
\text { Produktivitas }=\frac{\text { Biomassa }(\text { Ton })}{\text { Luas Tambak }(\mathrm{Ha})}
$$

b. Survival Rate (SR) menurut Purnamasari et al., (2017)

$$
\mathrm{SR}=\frac{\text { Jumlah udang sampling (ekor) }}{\text { Jumlah udang tebar (ekor) }} \times 100
$$

c. Food Convertion Ratio (FCR) menurut Dahlan et al., (2017).

$$
\mathrm{FCR}=\frac{\text { Total pakan yang diberikan }(\mathrm{kg})}{\text { Biomassa }(\mathrm{kg})}
$$

d. Average Body Weight (ABW) menurut Purnamasari et al., (2017)

$$
\mathrm{ABW}=\frac{\text { Berat Udang Yang Terjala }(\mathrm{gram})}{\text { Jumlah udang yang terjala (ekor) }}
$$

e. Average Daily Growth (ADG) menurut Witoko et al., (2018)

$$
A D G=\frac{A B W \text { II (gram) }-A B W I(g r a m)}{T \text { (hari) }}
$$


Buletin JSJ, 1 (2), 2019, 63-69

Available online di: http://ejournal-balitbang.kkp.go.id/index.php/JSJ/index

\section{HASIL DAN PEMBAHASAN}

Hasil performansi kinerja budidaya di PT. Buana Bersama Jayaindo secara umum belum dapat mencapai target perusahan. Berikut Target produksi perusahaan dapat dilihat pada Tabel 1.

Tabel 1. Target produksi perusahaan

\begin{tabular}{clccc}
\hline No & \multicolumn{1}{c}{ Indikator } & Satuan & Standar & Hasil \\
\hline 1. & Produktivitas & ton/ha/siklus & Min. 25 & $8-20$ \\
2. & SR & $\%$ & 80 & $52-98$ \\
3. & FCR & - & 1.5 & $1.3-1.8$ \\
4. & ABW & g/ekor & 25 & $11-20$ \\
5 & ADG & g/hari & 0.35 & $0.13-0.38$ \\
6. & Size Panen & - & 40 & $50-87$ \\
7. & Umur Panen & Hari & 100 & $76-94$ \\
\hline
\end{tabular}

\section{Produktivitas}

Produktivitas merupakan salah satu faktor penentu peningkatan hasil produksi kegiatan usaha budidaya. Produktivitas udang vaname di PT. BBJ pada siklus 2 belum mencapai target perusahaan. Produktivitas tambak pada siklus 2 berkisar antara 8-20 ton/ha. Target produktivitas yang ditetapkan perusahaan yaitu minimal 25 ton/ha. Pencapaian produktivitas pada masing-masing petak tambak yang diamati dapat dilihat pada Gambar 1.

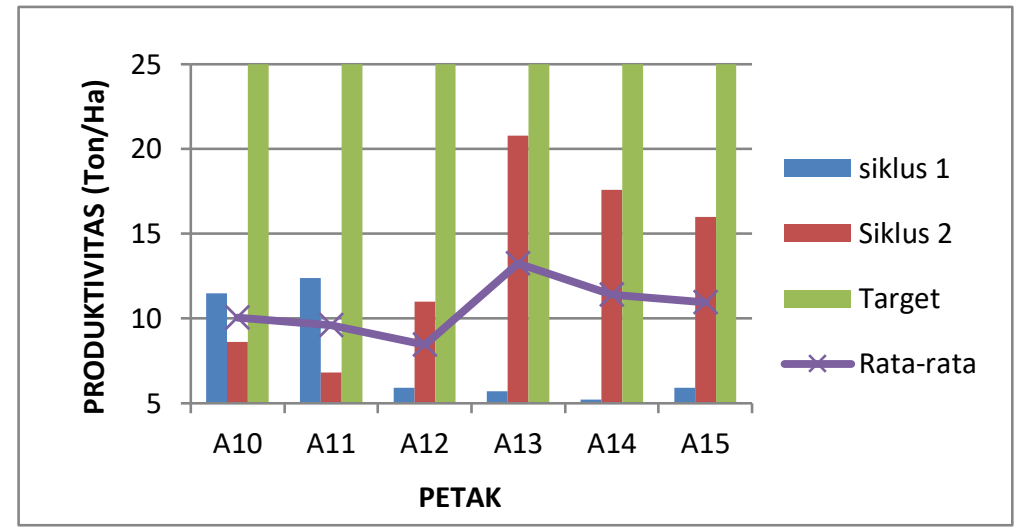

Gambar 1. Produktivitas Udang Vaname Selama Dua Siklus Pemeliharaan

Berdasarkan Gambar 1 dapat diketahui bahwa dari 6 petak tambak yang diamati, tidak ada satu pun petak tambak yang memenuhi target produktivitas yang diterapkan perusahan. Petak yang tidak mencapai target dikarenakan serangan IMNV yang menyerang petak tambak, sehingga harus dilakukan pemanenan lebih awal, selain hal itu rendahnya produktivitas pada siklus 2 juga disebabkan karena nilai ABW tidak mencapai target pada semua petakan.

\section{Survival Rate (SR)}

Survival Rate merupakan salah satu parameter untuk mengetahui tingkat kelangsungan hidup suatu organime (Permanti et al., 2018). SR yang dihasilkan pada siklus 2 berkisar antara 52$98 \%$ dan rata-rata SR yang di dapat yaitu $77 \%$. Sedangkan target SR yang ditetapkan perusahaan yaitu $80 \%$. Sedangkan berdasarkan Widigdo (2013) menyatakan bahwa SR pada siklus 1 yang di dapat PT. BBJ termasuk kategori sedang dan pada siklus 2 masuk kategori baik yaitu $>70 \%$. 
Buletin JSJ, 1 (2), 2019, 63-69

Available online di: http://ejournal-balitbang.kkp.go.id/index.php/JSJ/index

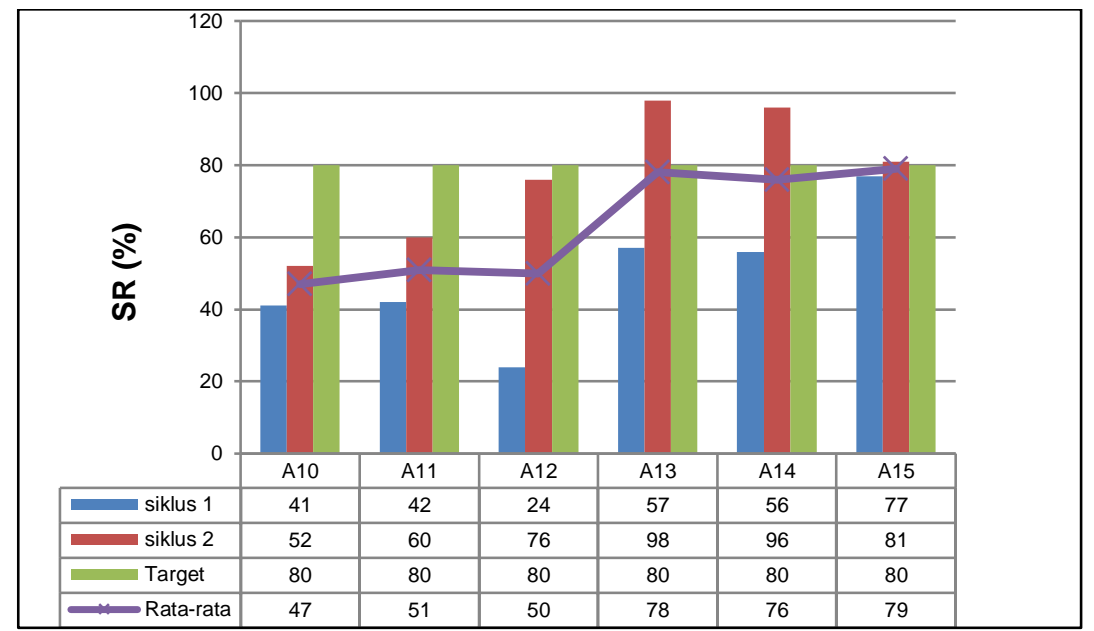

Gambar 2. Nilai SR Selama Pemeliharaan

Berdasarkan Gambar 2. dapat dilihat bahwa bahwa hanya 3 petak yang mampu memenuhi target perusahan yaitu pada petak A13, A14 dan A15 masing-masing sebesar $98 \%, 96 \%$ dan $81 \%$. Sedangkan pada siklus 1 tidak ada petak yang mempunyai nilai SR yang mencapai target perusahan.

\section{Food Convertion Ratio (FCR)}

FCR yang diperoleh cenderung tinggi atau melebihi target perusahan. Kisaran FCR pada siklus 2 yaitu 1.3-1.9, sedangkan target yang di tetapkan yaitu1.5. Berdasarkan target perusahan hanya terdapat 2 petak tambak yang mampu mencapainya yaitu petak A13 dan A14. Hasil pencapaian nilai Konversi pakan dapat dilihat pada Gambar 3.

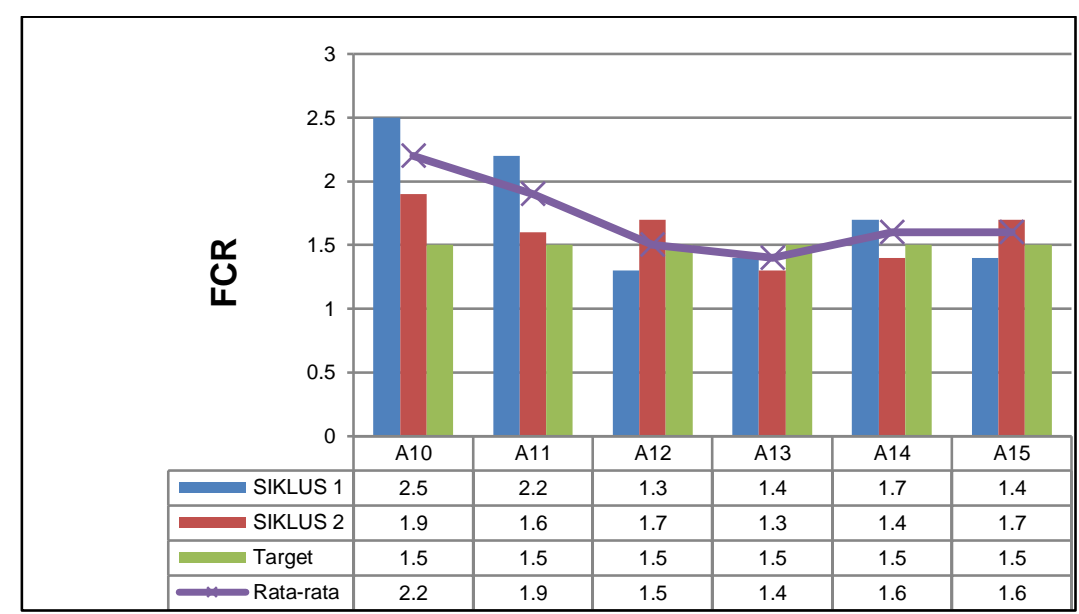

Gambar 3. Hasil Pencapaian FCR

Pencapaian konversi pakan pada siklus 2 apabila dibandingkan dengan siklus sebelumnya yaitu siklus 1 mengalami peningkatan. Hal ini di sebabkan pada siklus 1 kurangannya pengontrolan pemberian pakan. Nilai konversi rata-rata pada siklus 2 yaitu 1.6 sedangkan pada siklus sebelumnya lebih tinggi yaitu 1.8. Bagusnya nilai FCR yang diperoleh dapat dilihat dari rendahnya nilai FCR yang didapatkan selama masa pemeliharaan. Hal itu sesuai pendapat Sopha et al. (2015) bahwa semakin rendah nilai FCR semakin besar keuntungan yang akan didapatkan karena semakin kecil biaya yang akan di keluarkan untuk pembelian pakan udang. Serta nilai FCR berbanding terbalik dengan pertambahan bobot udang. Semakin rendah nilai FCR dan semakin tinggi penambahan bobot udang maka pertumbuhan udang semakin bagus (Dahlan et al., 2017). 
Buletin JSJ, 1 (2), 2019, 63-69

Available online di: http://ejournal-balitbang.kkp.go.id/index.php/JSJ/index

\section{Average Body Weight (ABW)}

Rata-rata berat udang yang didapatkan tidak dapat mencapai target perusahaan. Target ratarata berat udang yang ditetapkan oleh perusahaan yaitu $25 \mathrm{~g} / \mathrm{ekor}$. Sedangkan hasil rata-rata berat udang saat panen pada siklus 2 yaitu antara 11-20 g/ekor.

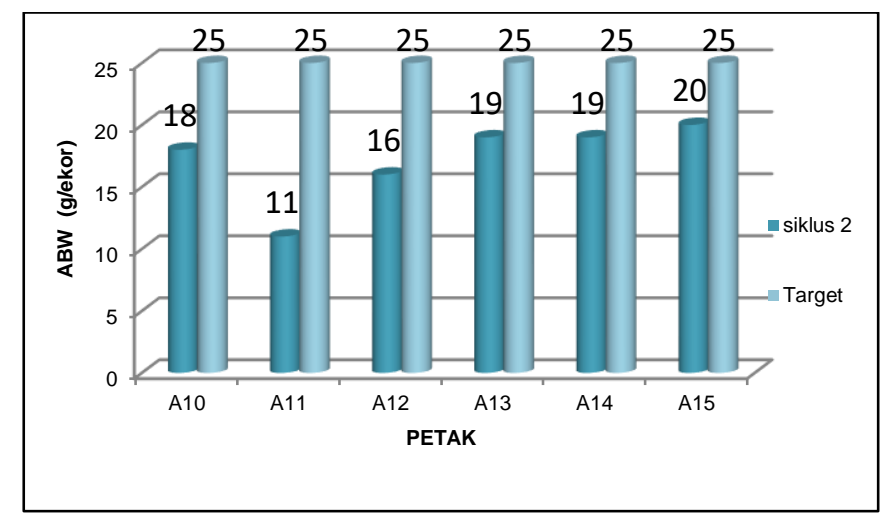

Gambar 4. Hasil Pencapaian ABW

Rata-rata berat udang terendah yang didapat pada siklus 2 terdapat pada petak A11. Hal ini diindikasikan bahwa pada petak tersebut terkena penyakit Infectious Myo Necrosis Virus (IMNV). Karena pada saat udang usia pemeliharaan 45 hari sudah terlihat gejalanya seperti udang berenang pasif, pucat, penurunan nafsu makan dan mortalitas udang meningkat. Hal itu sesuai dengan pendapat (Rekasana et al., 2013) bahwa Penyakit IMNV dapat menganggu sistem motorik dan nafsu makan udang akan berkurang. Penyakit IMNV pada petak 11 menyerang ketika udang memasuki umur 70 hari pemeliharaan. Kemudian dilakukan tindakan pemanenan lebih awal pada umur 76 hari pemeliharaan, karena mortalits udang yang semakin meningkat setiap harinya. Dan rata-rata berat udang tertinggi terdapat pada petak A15 yaitu sebesar 20 gram/ekor.

\section{Average Daily Growth (ADG)}

Rata-rata pertumbuhan harian udang belum mencapai target produksi. Target ADG yang di rancang perusahan yaitu $0.35 \mathrm{~g} / \mathrm{ekor}$ per hari. Sedangkan hasil rata-rata ADG sampling pada siklus 2 yaitu antara 0.15-0.32. Namun dilihat dari taerget ADG SNI No. 01-7246 (2006) yaitu $0.2 \mathrm{~g} / \mathrm{ekor}$ per hari, udang telah melebihi target. Rata-rata ADG udang pada 6 petak tambak dapat dilihat pada Gambar 5.

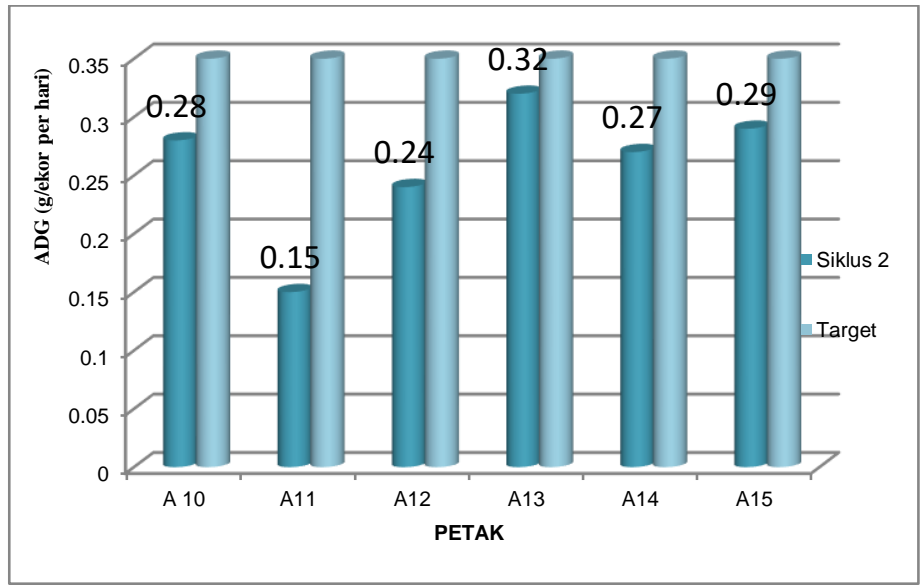

Gambar 5. Nilai Rata-rata ADG Selama Pemeliharaan 
Buletin JSJ, 1 (2), 2019, 63-69

Available online di: http://ejournal-balitbang.kkp.go.id/index.php/JSJ/index

Berdasarkan Gambar 5 dapat dilihat bahwa petak A11 merupakan petak dengan rata-rata ADG terendah. Pada sampling ke-2 dan ke-3 nilai ADG pada petak A11 merupakan nilai tertinggi dibandingkan petak yang lainnya. Akan tetapi nilai ini semakin menurun pada sampling berikutnya, hal itu disebabkan petak A11 terkena IMNV sehingga nafsu makan udang menurun dan terjadi mortalitas yang tinggi pada petak tersebut. Hal ini sependapat dengan Sukenda (2013) bahwa udang yang terkena IMNV akan terjadi penurunan nafsu makan dan akan mengakibatkan mortalitas tinggi.

\section{Kualitas Air}

Kualitas air merupakan hal yang harus diperhatikan karena memberikan pengaruh yang cukup besar terhadap kelangsungan hidup dan pertumbuhan udang. Nilai kisaran kualitas air selama pemeliharaan udang disajikan pada Tabel 2.

Tabel 2. Nilai Kisaran Kualitas Air Pemeliharaan

\begin{tabular}{|c|c|c|c|c|c|c|c|c|}
\hline \multirow{2}{*}{ Parameter } & \multicolumn{6}{|c|}{ Petak } & \multirow{2}{*}{ Standar } & \multirow{2}{*}{ Ket. } \\
\hline & A 10 & A 11 & A 12 & A 13 & A 14 & A 15 & & \\
\hline \multicolumn{9}{|l|}{ Suhu $\left({ }^{0} \mathrm{C}\right)$} \\
\hline 06.30 WIB & 29.7 & 29.6 & 29.4 & 29.7 & 29.7 & 29.7 & $30-33$ & Sesuai \\
\hline 16.30 WIB & 30.4 & 30.4 & 30.2 & 30.4 & 30.4 & 30.4 & & \\
\hline Salinitas $(g / l)$ & 30.4 & 30.4 & 30.4 & 30.4 & 30.4 & 30.4 & $10-32$ & Sesuai \\
\hline $\mathrm{pH}$ & 7.91 & 7.85 & 7.9 & 7.8 & 7.91 & 7.78 & $7.5-8.5$ & Sesuai \\
\hline $\mathrm{DO}(\mathrm{mg} / \mathrm{l})$ & 6.5 & 6.4 & 6.37 & 6.55 & 6.68 & 6.42 & Min. 4 & Sesuai \\
\hline Nitrit $(\mathrm{mg} / \mathrm{l})$ & 0.06 & 0.1 & 0.12 & 0.05 & 0.07 & 0.08 & $<1$ & Sesuai \\
\hline Alkalinitas (mg/l) & 115.2 & 119.2 & 119.2 & 121.6 & 124 & 120.7 & $100-150$ & Sesuai \\
\hline
\end{tabular}

Berdasarkan Tabel 2 dapat dikatan bahwa kualitas air pemeliharaan udang vaname di PT. BBJ telah sesuai standar, namun dilihat secara keseluruhan terhadap kualitas air pemeliharaan belum dikatakan optimal, karena kurangnya ketersediaan alat kualitas air sehingga pengujian terhadap kualitas air tidak dilakukan optimal.

\section{KESIMPULAN}

Hasil performansi kinerja budidaya pada siklus 2 belum mencapai target perusahan, namun mengalami peningkatan dari siklus sebelumnya. Hasil rata-rata performansi kinerja budidaya pada siklus 2 yaitu; produtivitas 13,47 Ton/Ha, SR 77 \%, FCR 1,6, ABW 17,2 g/ekor dan ADG $0,26 \mathrm{~g} / \mathrm{ekor}$ per hari.

\section{DAFTAR PUSTAKA}

Dahlan J, Muhaimin H dan Agus K. 2017. Pertumbuhan Udang Vaname (Litopenaeus vannamel) yang Dikultur pada Sistem Bioflok dengan Penambahan Probioti. Jurnal Sains dan Inovasi Perikanan.

Gufron M, Lamid M, Putri D. W. S, dan Hari S. 2017. Teknik Pembesaran Udang Vaname (Litopenaeus vannamei) Pada Tambak Pendampingan Pt Central Proteina Prima Tbk di Desa Randutatah, Kecamatan Paiton, Probolinggo, Jawa Timur. Journal of Aquaculture and Fish Health Vol. 7.

Permantia Y. C, Pande G. S. J dan Made A. P. 2018. Pengaruh Penambahan Bacillus sp. Terhadap Kelulusan hidup Pasca Larva Udang Vannamei (Litopenaeus vannamei) Yang Terinfeksi Vibriosis. Journal Current Trends in Aquatic Science I(I), 89-95 
Buletin JSJ, 1 (2), 2019, 63-69

Available online di: http://ejournal-balitbang.kkp.go.id/index.php/JSJ/index

Purnamasari I, Dewi P dan Maya A. F. U. 2017. Pertumbuhan Udang Vaname (Litopenaeus vannamei) di Tambak Intensi. Jurnal Enggano. vol. 2 no. 1, 58-67.

Rekasana A, Laksmi S dan Soedarno . 2013. Distribusi Penyakit Infectious Myo Necrosis Virus (IMNV) Pada Udang Vannamei (Litopenaeus Vannamei) Di Pantai Utara Jawa Timur. Jurnal IImiah Perikanan dan Kelautan Vol. 5 No. 1

Ruswahono, A. 2011. Pengelolaan Media Budidaya Dalam Upaya Pencegahan Penyakit Pada Pembesaran Udang Vannamei (L.vannamei) Teknologi Intensif Di PT. Segara Indah Kecamatan Besuki. Tulung agung Jawa Timur.

SNI. No. 01. 7246. 2006. Produksi Udang Vaname (Litopenaeus vannamei) di Tambak Dengan Teknologi Intensif

Sopha, S., L. Santoso, B. Putri. 2015. Pengaruh Substitusi Parsial tepung Ikan dengan Tepung Tulang Terhadap Pertumbuhan Ikan Lele Sangkuriang (Clarias gariepenus). Jurnal Rekayasa dan Teknologi Budidaya Perairan. 3(2): 403-409.

Sukenda, Nuryati, S. \& Sari, I. R. 2011. Pemberian meniran Phyllanthus niruri untuk pencegahan infeksi IMNV (infectious myonecrosis virus) pada udang vaname (Litopenaeus vannamei. Jurnal Akuakultur Indonesia 10 (2), 192-202 (2011).

Widigdo B. 2013. Bertambak Udang dengan Teknologi Biocrete. Kompas Media Nusantara: Jakarta.

Witoko P, Ninik P dan Nuning M. N. 2018. Analisis Kelayakan Usaha Budidaya Udang Vanname (Litopenaeus vannameI) di Keramba Jaring Apung Laut. Manajemen IKM. Vol. 13 No. 2: 175-179. 